\title{
Legislation governing pluripotent stem cells in South Africa
}

\author{
M S Pepper, ${ }^{1}$ MB ChB, PhD, MD; C Gouveia, ${ }^{2}$ BSc, BSc Hons; M Nőthling Slabbert, ${ }^{3}$ BA, BA Hons, MA DLitt, LLB, LLD \\ 'Department of Immunology, Institute for Cellular and Molecular Medicine, and MRC Extramural Unit for Stem Cell Research and Therapy, Faculty of \\ Health Sciences, University of Pretoria, South Africa; Department of Genetic Medicine and Development, Faculty of Medicine, University of Geneva, \\ Switzerland \\ ${ }^{2}$ Department of Immunology, Institute for Cellular and Molecular Medicine, and MRC Extramural Unit for Stem Cell Research and Therapy, Faculty of \\ Health Sciences, University of Pretoria, South Africa \\ ${ }^{3}$ Department of Jurisprudence, School of Law, University of South Africa, Pretoria, South Africa
}

Corresponding author: M S Pepper (Michael.pepper@up.ac.za)

\begin{abstract}
One of the most exciting areas of medical research involves the use of stem cells for the treatment of patients with a variety of diseases and for tissue repair. Although stem cell research is accelerating rapidly in many countries, it has in the past been limited in South Africa (SA); very little has been done in this country to explore the great potential offered by stem cells to address the high disease burden. Stem cell therapy has however been practised for many years, in SA and worldwide, in the form of haematopoietic stem cell transplantation, mainly for haematological malignancies. From a therapeutic perspective, two types of stem cells can be defined: pluripotent stem cells and adult stem cells. Pluripotent cells derived from the inner cell mass of blastocysts (either from in vitro fertilisation or following somatic cell nuclear transfer) are called embryonic stem (ES) cells, while those derived by reprogramming adult cells are called induced pluripotent stem (iPS) cells. Adult stem cells include haematopoietic, mesenchymal and neural stem cells.

The purpose of this article is to critically examine the SA legislation with regard to elements that impact on pluripotent stem cell research and the use of pluripotent stem cells for therapeutic purposes. This includes (but is not limited to) legislation from the National Health Act (Chapter 8 in particular) and its regulations, and deals with matters related to research on embryos in the stem cell context, somatic cell nuclear transfer, reproductive and therapeutic cloning and the generation and therapeutic use of iPS and ES cells.
\end{abstract}

S Afr J BL. 2015;8(2 Suppl 1):23-31. DOI:10.7196/SAJBL.8402

In order to be defined as a stem cell, a cell must be able to divide to ensure self-renewal, and to differentiate (Fig. 1). The earliest stem cell from a developmental perspective is the fertilised egg (zygote) (Fig. 2).

The zygote is totipotent, i.e. it is capable of giving rise to all of the extraembryonic and embryonic tissues of the developing embryo. As development progresses, the differentiation potential of successive

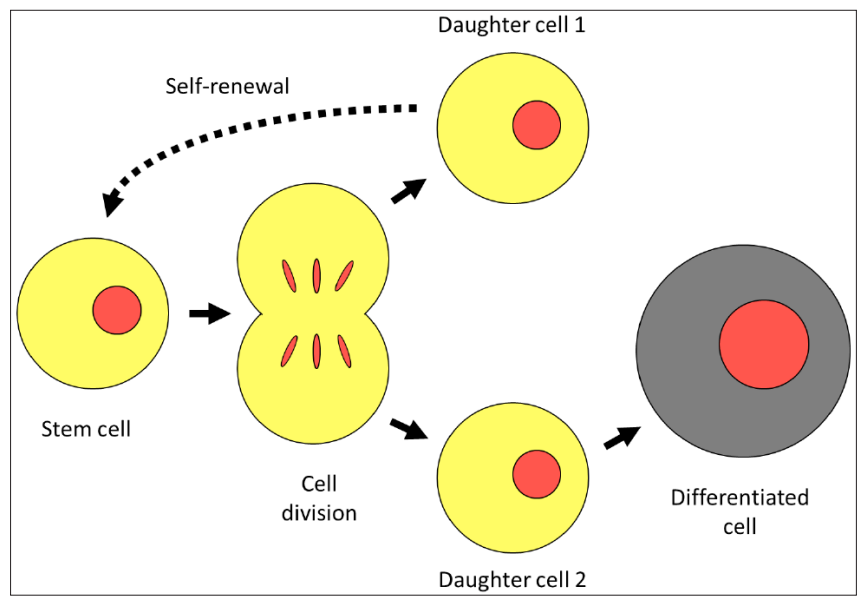

Fig. 1. Definition of a stem cell. In order to be defined as a stem cell, a cell must be able to divide and to differentiate. To ensure a continuing source of cells capable of self-renewal, at least one of the resulting daughter cells should remain a stem cell. populations of stem cells becomes restricted, and cells are said to be pluripotent, multipotent and finally unipotent. Progenitor cells have a limited number of cell divisions and may be multipotent or unipotent.

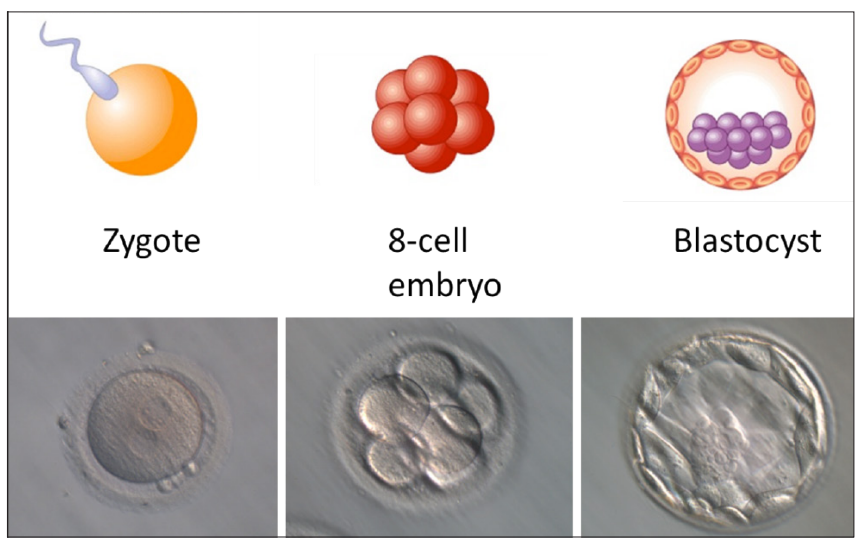

Fig. 2. From fertilisation to blastocyst formation. A zygote results from the fertilisation of an egg by a sperm. After three rounds of division, an 8-cell embryo can be recognised, and following compaction and morula formation this goes on to form a blastocyst. The blastocyst consists of an inner cell mass which goes on to develop into the embryo proper, while the outer layer, the trophoblast, goes on to form the placenta. Micrographs in the lower half of the figure were provided by Prof. Carin Huyser (Reproductive Biology Laboratory, Department of Obstetrics and Gynaecology, University of Pretoria and Steve Biko Academic Hospital, Pretoria, South Africa). 
The adult human is made up of approximately $4 \times 10^{13}$ cells $_{1}^{[1]}$ and there are more than 200 different cell types in the human body. Approximately 200 million $\left(2 \times 10^{8}\right)$ cells are lost from the body of an adult per minute, and their replacement is assured by adult stem cells throughout life. Adult stem cells are found in most tissues including bone marrow, skin, skeletal muscle, intestinal mucosa, liver and neural tissue. With the exception of haematopoietic stem cells (HSCs), these cells are limited in number, are difficult to isolate and their therapeutic potential remains largely undefined. HSCs derived from the bone marrow, peripheral blood (following growth factor mobilisation of bone marrow cells) or neonatal blood (harvested immediately after birth via the umbilical cord from the placenta) have been used successfully and for several decades for haematopoietic stem cell transplantation (HSCT) for the treatment of neoplastic, haematological and genetic diseases.

Pluripotent stem cells, the topic of this article, are on the other hand more complex with regard to their derivation, and in some cases are associated with important ethical considerations. Their therapeutic potential is only beginning to be explored. Table 1 highlights the salient differences between adult and pluripotent stem cells.

Pluripotent stem cells include embryonic stem cells (ES cells) and induced pluripotent stem cells (iPS cells). ES cells are derived from the inner cell mass (ICM) of the blastocyst. Blastocysts are obtained either from IVF or following the process of somatic cell nuclear transfer (SCNT). The iPS cells are derived from adult cells which are induced to dedifferentiate following the introduction of genes which code for transcription factors involved in early embryonic development (Fig. 3). The derivation of pluripotent stem cells is summarised in Table 2.

ES and iPS cells can develop into almost every cell type in the body (hence their categorisation as pluripotent). ES and iPS cells have great potential value for understanding disease processes, for drug screening and potentially for therapeutic purposes, although the latter is only beginning to be

\section{Table 1. Adult v. pluripotent stem cells}

Adult

Differentiation potential generally limited

to cells of tissue in which they reside

Readily available

No ethical issues

No evidence for tumorigenesis

Therapeutic value well demonstrated

HSCs for bone marrow transplantation MSCs: $>500$ registered clinical trials

Pluripotent Differentiation potential: all of the body's cell types

Technically more difficult to obtain

Ethical issues related to ES cells

Potential for tumorigenesis

Therapeutic value - remains to be

determined

Value: understanding disease

processes, drug screening

MSCs = mesenchymal stem cells

Table 2. Pluripotent stem cells

\begin{tabular}{llll}
\hline Name & Origin & $\begin{array}{l}\text { Legislation } \\
\text { pertaining to } \\
\text { embryos applicable }\end{array}$ \\
\hline Embryonic stem cell & Blastocyst & $\begin{array}{l}\text { Derived from IVF } \\
\text { Derived by SCNT } \\
\text { (therapeutic cloning) }\end{array}$ & Yes \\
& & Yes & No \\
Induced pluripotent stem cell & Somatic cell & &
\end{tabular}

defined. However, ES cells, irrespective of the means through which they are derived, are the source of much controversy, since their isolation is interpreted by some as necessitating the destruction of life.

Finally, it should be noted that the 2012 Nobel Prize in physiology or medicine was awarded jointly to John B Gurdon and Shinya Yamanaka for the discovery that mature cells can be reprogrammed to become pluripotent. ${ }^{[2]}$

\section{Removal and/or withdrawal and use of human tissue, blood, blood products and \\ gametes}

Section 56 of Chapter 8 of the National Health Act (NHA) ${ }^{[3]}$ entitled 'Use of tissue, blood, blood products or gametes removed or withdrawn from living persons, stipulates in subsection (1) that ' $[a]$ person may use tissue or gametes removed or blood or a blood product withdrawn from a living person only for such medical or dental purposes as may be prescribed'. The interpretation of 'prescribed' is understood to mean established medical practice. Where this is not the case, it is understood that any other 'purposes' would first need to be validated in the context of a clinical trial. ${ }^{[4]}$

Subsection (2) stipulates that ministerial authorisation is needed for removal or withdrawal of tissue, blood, blood products or gametes from a living person under the following conditions:

'(i) Tissue, blood, a blood product or a gamete from a person who is mentally ill within the meaning of the Mental Health Care Act, 2002 (Act No. 17 of 2002);

(ii) tissue which is not replaceable by natural processes from a person younger than 18 years; (iii) a gamete from a person younger than 18 years; or

(iv) placenta, embryonic or foetal tissue, stem cells and umbilical cord, excluding umbilical cord progenitor cells.'

In the context of this article, the removal and/or withdrawal of the following from a living person therefore requires ministerial authorisation:

- Embryonic tissue (from conception to 8 weeks of gestation)

- Fetal tissue (from 9 weeks following conception to birth)

- Stem cells

- Placenta and umbilical cord. 
Specifically excluded from this requirement are umbilical progenitor cells. The reason for this exclusion probably relates to the regulator's understanding that stem cells from cord blood used in HSCT are limited to progenitor cells. There are, however, more primitive stem cells in cord blood, which are not progenitors that are likely to contribute to the success of engraftment following transplantation, as well as non-haematopoietic stem cells..$^{[5]}$ It is therefore understood that the removal and/or withdrawal of these cells would also require ministerial authorisation, since they are not specifically excluded. Since it is at present not possible to separate progenitors from the other stem cells on a routine basis, we would therefore interpret this to mean that removal and/or withdrawal of cord blood requires ministerial authorisation.

\section{Research on embryos in the stem cell context}

A human embryo is the product of a fertilised egg, from the zygote until the fetal stage ${ }^{[6]}$ or 'the developing organism from fertilization to the end of the eighth week. ${ }^{[7]} \mathrm{A}$ further distinction is made for the period from fertilisation until 14 days which is referred to as the pre-embryonic (or pre-implantation) stage.$^{[8]}$ Fourteen days after fertilisation also marks the stage at which an embryo begins to develop a nervous system. ${ }^{[9]}$

In 2002 the House of Lords in the UK published a report on stem cell research. ${ }^{[10]}$ Chapter 4 which deals with 'The Status of the Early Embryo' is in line with the previous recommendations of the 1984 Warnock Committee Report ${ }^{[11]}$ and concludes that 'Whilst respecting the deeply held views of those who regard any research involving the destruction of a human embryo as wrong and having weighed the ethical arguments carefully, the Committee is not persuaded, especially in the context of the current law and social attitudes, that all research on early human embryos should be prohibited ... If the respect to be accorded to an embryo increases as it develops, this is a gradual process and it may be difficult to establish precisely the point of transition from one stage to the next. The [Human Fertilisation and Embryology] 1990 Act established 14 days as the limit for research on early embryos. Fourteen days has an objective justification insofar as it represents the stage at which the primitive streak, the precursor of the development of a nervous system, begins to appear. This limit seems to have been widely accepted, and the research done under the Act under licence from the HFEA [Human Fertilisation and Embryology Authority] has attracted very little criticism from those who accept the case for research on early embryos. We have received no evidence to suggest that,

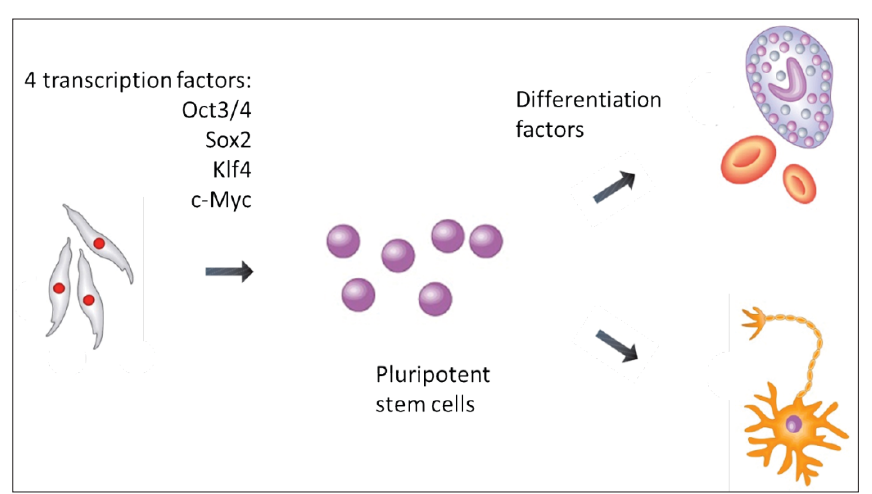

Fig. 3. Induced pluripotent stem (iPS) cells. iPS cells are derived from differentiated human somatic cells which are reprogrammed (dedifferentiated) to a pluripotent state. This is achieved by the introduction and expression of 4 transcription factors - Oct4, Sox2, Klf4 and c-Myc-into the somatic cells of interest. if research on human embryos is to continue, there should be a different limit. In point of fact the stage at which stem cells need to be extracted for research is very much earlier than that - at the blastocyst stage - when the early embryo is still smaller than a pinhead. The Committee considers that 14 days should remain the limit for research on early embryos. The 14 day limit was also recommended by the Waller Committee in Victoria, Australia, in 1984. ${ }^{[12]}$

With regard to definitions in the South African legislation, an embryo is defined in the NHA as'a human offspring in the first eight weeks from conception' (Annexure). Use of the word offspring is not appropriate and we would suggest replacing the definition with 'the early stages of human growth and development, from conception to the eighth week'

Removal and/or withdrawal of tissue from a living human embryo requires ministerial authorisation. Tissue is defined in the NHA as 'human tissue, and includes flesh, bone, a gland, an organ, skin, bone marrow or body fluid, but excludes blood or a gamete', and in the Regulations Relating to Tissue Banks ${ }^{[13]}$ as'a functional group of cells. The term is used collectively in the Regulations to indicate both cells and tissue'.

Subsection 57(4) of Chapter 8 of the NHA stipulates that ' $[t]$ he Minister may permit research on stem cells and zygotes which are not more than 14 days old on a written application and if $(a)$ the applicant undertakes to document the research for record purposes; and $(b)$ prior consent is obtained from the donor of such stem cells or zygotes'. It is presumed that 'cells and zygotes' should be interpreted as a pre-embryo, as defined above. The Act is however silent on research on embryos from 14 days to 8 weeks of gestation.

Section 57(3) provides that '[n]o person may import or export human zygotes or embryos without the prior written approval of the Minister'.

In summary, removal and/or withdrawal of tissue from a living human embryo requires ministerial authorisation. It is not clear, however, whether 'use' of this tissue, once removed from a 3-8 week embryo, requires ministerial authorisation. Irrespective, such 'use' will require the approval of a registered research ethics committee.

\section{Somatic cell nuclear transfer}

The procedure of SCNT can be described as the removal of the chromosomes (constituted as the meiotic spindle complex) from an oocyte, followed by the transfer and fusion of a donor somatic cell nucleus to the enucleated oocyte. The manipulated oocyte is then artificially activated which should induce subsequent development of the embryo (Fig. 4).

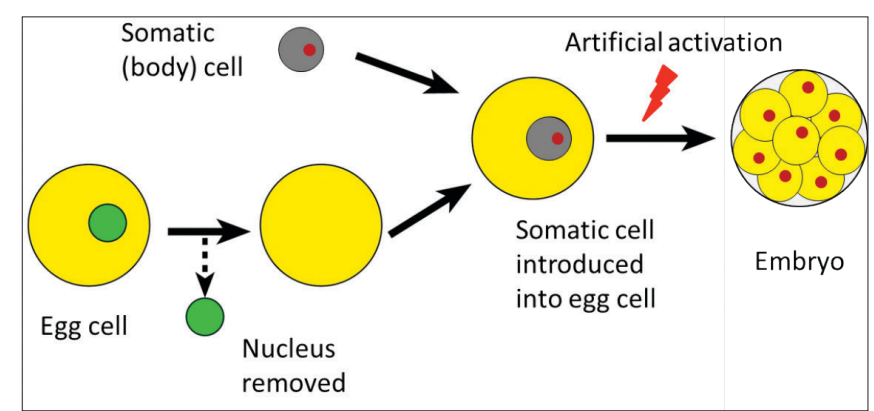

Fig. 4. Somatic cell nuclear transfer (SCNT). SCNT involves the removal of the chromosomes (constituted as the meiotic spindle complex) from an oocyte, followed by the transfer and fusion of a donor somatic cell nucleus to the enucleated oocyte. The manipulated oocyte is then artificially activated which should induce subsequent development of the embryo. 
SCNT is currently being performed in several laboratories worldwide for the purpose of creating human stem cells. In the UK for example, human SCNT research is legal and in 2001 was incorporated into the Human Fertilisation and Embryology Act 1990 (HFEA). However, before performing SCNT it is necessary to obtain permission from the HFEA. In the USA, SCNT research is also legal but may not be funded by the federal government as a result of the Dickey-Wicker Amendment bill passed in 1995. The Department of Health and Human Services and the National Institutes of Health prohibits the use of funds for research studies involving the creation of human embryos and the destruction thereof. SCNT research aimed at producing human ES cells may nonetheless be legally performed when funded by private or non-governmental organisations.

Strict regulation of human SCNT research should be maintained by registered research ethics committees, as well as by ethical guidelines that have been set by the US National Academy of Science, the International Society for Stem Cell Research (ISSCR), and the American Society for Reproductive Medicine. ${ }^{[14]}$ As reviewed by Cervera and Mitalipov, ${ }^{[15]}$ there are several ethical and legal issues associated with SCNT, one of the most important of which is access to human oocytes. The ideal approach would be to identify donors willing to provide oocytes for research without any reimbursement. According to one study, however, women are simply not prepared to undergo ovarian stimulation and invasive oocyte retrieval without being reimbursed for their efforts. ${ }^{[16]}$

The ISSCR 'Position Statement on the Provision and Procurement of Human Eggs for Stem Cell Research ${ }^{[17]}$ recommends that'[p]aying (in cash or kind) women for providing eggs for research is ethically justifiable as a means of compensating them for their time, inconvenience, willingness to accept some risks, and reimbursement for out-of-pocket expenses. This is not a payment for the eggs themselves'. Other observations and/ or recommendations include the unethical nature of using financial incentives to induce donation, the need for review by a registered research ethics committee, the need to separate fertility treatments from egg donation, the need for standard operating procedures in accredited institutions and for donor follow-up after donation, and vigilance with regard to cross-border donation and trafficking. Local laws regulating compensation for oocyte donors may also govern the procurement of human oocytes for research purposes. In California, for example, patients donating oocytes for research purposes are covered for certain expenses but are not reimbursed for 'time, effort and inconvenience.' In Oregon, on the other hand, research oocyte donors are fully compensated in a manner that is equal to reproductive oocyte donors. ${ }^{[18]}$

With regard to the situation in South Africa, subsection 60(1)(a) of Chapter 8 of the NHA, entitled 'Payment in connection with the importation, acquisition or supply of tissue, blood, blood products or gametes', stipulates that 'a hospital or an institution contemplated in section 58(1)(a), a person or an institution contemplated in section 63 and an authorised institution or, in the case of tissue or gametes imported or exported in the manner provided for in the regulations, the importer or exporter concerned, may receive payment in respect of the acquisition, supply, importation or export of any tissue or gamete for or to another person for any of the purposes contemplated in section 56 or 64 . This is further detailed in subsections (2), (3), (4) and (5) as follows:

'(2) The amount of payment contemplated in subsection (1) may not exceed an amount which is reasonably required to cover the costs involved in the importation, export, acquisition or supply of the tissue, gamete, blood or blood product in question.

(3) This section does not prevent a health care provider registered with a statutory health professional council from receiving remuneration for any professional service rendered by him or her.

(4) It is an offence for a person

(a) who has donated tissue, a gamete, blood or a blood product to receive any form of financial or other reward for such donation, except for the reimbursement of reasonable costs incurred by him or her to provide such donation; and

(b) to sell or trade in tissue, gametes, blood or blood products, except as provided for in this Chapter.

(5) Any person convicted of an offence in terms of subsection (4) is liable on conviction to a fine or to imprisonment for a period not exceeding five years or to both a fine and such imprisonment.'

Further guidance regarding the legal position relating to egg donation in South Africa is found in the Regulations Relating to Artificial Fertilisation of Persons. ${ }^{[19]}$ A gamete donor 'means a living person from whose body a gamete or gametes are removed or withdrawn, for the purpose of artificial fertilisation'. With regard to compensation, clause 4 states that '[a] person from whose body a gamete has been removed or withdrawn may be reimbursed for any reasonable expenses incurred by him or her in order to donate a gamete as contemplated in section 60(4)(a) of the (National Health) Act. Clauses 6 and 7 stipulate that only six children may be conceived through artificial fertilisation from a single gamete donor.

It should be noted that the NHA and the regulations are silent regarding egg donation for research purposes.

Further details regarding payment are provided in the 2008 guidelines of the Southern African Society for Reproductive Medicine and Gynaecological Endoscopy (SASREG). ${ }^{[20]}$ With regard to payment of oocyte donors, the guidelines state that ' $[\mathrm{m}]$ onetary compensation of the donor should reflect the time, inconvenience, financial costs to the donor - e.g. travel, loss of income and childcare costs, physical and emotional demands and risks associated with oocyte donation and should be at a level that minimizes the possibility of undue inducement of donors and the suggestion that payment is for the oocytes themselves. The monetary compensation should not be predicated on the clinical outcome (no. of oocytes or pregnancy outcome) but rather on fair compensation for the procedure of donating eggs [...] Donors should only receive financial compensation via fertility clinics and not receive any compensation directly from the recipients or other third parties'. In an amendment of 25 November 2014 it is stipulated that '[e]gg donors should not be compensated more than R7 000 per procedure from 1 January 2015.[21]

As a result of the ethical and financial limitations related to reimbursement of oocyte donors, alternative sources of human oocytes have been investigated for SCNT research. Immature oocytes, which are generally discarded in assisted reproductive procedures, are voluntarily donated by patients for research purposes. However, in vitro maturation, fertilisation, and subsequent development of these immature oocytes to the blastocyst stage are highly compromised following SCNT, and are therefore not appropriate for optimisation of the SCNT procedure. ${ }^{[22,23]}$

It should be noted that the use of high-quality human oocytes in SCNT does not guarantee successful embryo development to the 
blastocyst stage. In a study conducted by Noggle and colleagues, ${ }^{[24]}$ successful blastocyst development and subsequent isolation of ESCs was only observed in those embryos that had somatic cells transferred to non-enucleated oocytes. This observation may have implied that molecules essential for proper reprogramming of the somatic cell nucleus might be removed during enucleation, which are supposedly retained by the presence of the oocyte's own chromosomes. Another study that observed early failure in monkey SCNT embryo development, also assumed that the cause was related to the removal of reprogramming factors during enucleation possibly linked to the oocyte's chromosomes. ${ }^{[25]}$ Subsequent studies have however proven otherwise, namely that the oocyte's chromosomes are not a prerequisite for the successful reprogramming of the somatic cell nuclear genome. ${ }^{[26]}$ Nevertheless, many studies encourage that each step in SCNT be thoroughly optimised and adapted specifically for human oocytes. In summary, a major drawback related to rigorous testing on human oocytes is the requirement of a large number of good quality human oocytes, which remains limited. ${ }^{[1]}$

From an ethical point of view, the intentional creation of embryos using SCNT is condemned for a variety of reasons. It is seen to diminish human individuality and integrity, and the freedom, identity and dignity of the human person (in the sense that many identical copies of the same DNA may be created). It could also be viewed as impacting on human reproductive autonomy, as an embryo is created with only one genetic parent to whom the embryo would be genetically identical. Researchers should be cognizant of these concerns, which are fundamental to our understanding of humanity, human identity, the inviolability of the human person, human reproduction and human dignity. Global consensus on the ban of reproductive cloning in the form of the UN Declaration on Human Cloning (2005) ${ }^{[27]}$ has unfortunately cast a shadow on the use of SCNT in the context of 'therapeutic cloning', incorrectly equated with 'reproductive cloning'.

\section{Reproductive and therapeutic cloning}

Blastocysts derived by SCNT can be utilised in two ways (Fig. 5). In the first, the blastocyst is placed in the uterus of a surrogate mother and if

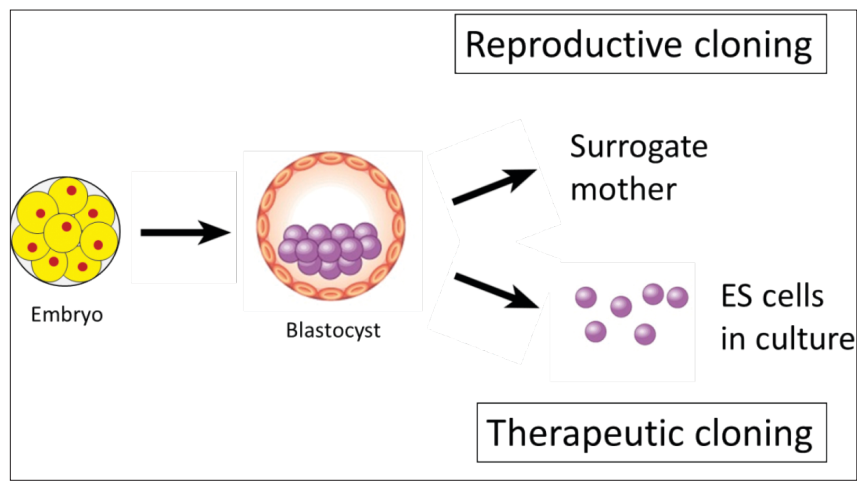

Fig. 5. Reproductive and therapeutic cloning. Blastocysts derived by SCNT can be utilised in two ways. In the first, the blastocyst is placed in the uterus of a surrogate mother and if development occurs to term, the resulting offspring will have been derived by a process referred to as 'reproductive cloning'. In the second, cells derived from the ICM of the blastocyst are grown in tissue culture to form ES cells. The nuclear genome of these cells is identical to that of the somatic cell donor. This process is referred to as 'therapeutic cloning'. development occurs to term, the resulting offspring will be identical to the somatic cell donor and will have been derived by a process referred to as 'reproductive cloning'. In the second, cells derived from the ICM of the blastocyst are grown in tissue culture to form ES cells. This process is referred to as 'therapeutic cloning' since the ES cells are autologous as the nuclear genome of these cells is identical to that of the somatic cell donor. (Note that the mitochondrial genome will be a mosaic between the oocyte donor and the somatic cell donor). Use of these cells in the donor would not require immunosuppression, as would be the case if the cells were allogeneic.

Reproductive cloning of a human being is defined in subsection 57(6)(a) of Chapter 8 of the NHA as 'the manipulation of genetic material in order to achieve the reproduction of a human being and includes nuclear transfer or embryo splitting for such purpose' (Annexure). We would suggest replacing this with 'the manipulation of cells, gametes, zygotes or embryos or genetic material derived therefrom in order to achieve reproduction of a human being and includes but is not limited to nuclear transfer and embryo splitting'.

Subsection 57(1) of Chapter 8 of the NHA, entitled 'Prohibition of reproductive cloning of human beings', stipulates that a person may not

'(a) manipulate any genetic material, including genetic material of human gametes, zygotes or embryos; or

(b) engage in any activity, including nuclear transfer or embryo splitting, for the purpose of the reproductive cloning of a human being.'

Therapeutic cloning is defined in section 57(6)(b) of Chapter 8 of the $\mathrm{NHA}$ as'the manipulation of genetic material from either adult, zygotic or embryonic cells in order to alter, for therapeutic purposes, the function of cells or tissues' (Annexure). This definition is problematic as it is much broader and less specific than the recognised procedure for reproductive cloning, which as described above is SCNT. We would recommend the inclusion of SCNT in the definition.

In contrast to reproductive cloning, subsection 57(2) of Chapter 8 of the NHA provides that ' $[\mathrm{t}]$ he Minister may, under such conditions as may be prescribed, permit therapeutic cloning utilising adult or umbilical cord stem cells'.

According to subsection 57(5) of Chapter 8 of the NHA, '[a]ny person who contravenes a provision of this section or who fails to comply therewith is guilty of an offence and is liable on conviction to a fine or to imprisonment for a period not exceeding five years or to both a fine and such imprisonment'.

In summary, reproductive cloning is banned in SA. Therapeutic cloning is permitted but requires ministerial authorisation since this involves 'research on stem cells and zygotes which are not more than 14 days.' This is summarised in Table 2.

\section{Embryonic stem cells}

Embryonic stem cells are derived from the ICM of the blastocyst. In humans, the blastocyst is equivalent to a 5-day-old embryo. The ICM, which consists of approximately 100 cells, is manually removed from the (pre-)embryo and is placed in tissue culture under specific conditions. ${ }^{[28]}$ The resulting cells are termed ES cells and are pluripotent in nature.

Two methods can be used to obtain a blastocyst. The first is IVF and the second is SCNT (discussed above). 
There are several views as to when human life begins. These include:

- at the moment of fertilisation

- with the development of the first organ system (heart and blood vessels)

- at the moment of perceived consciousness

- from the moment the fetus is able to survive outside the uterus (22-24 weeks).

These perceptions may explicitly or implicitly influence considerations relating to the possible uses, creation and 'destruction' of human embryos for research purposes, more so when research activities involving the human embryo are legally defined. As described in the section on Research on embryos in the stem cell context above, the 14-day limit following fertilisation, after which embryos may not be permitted to develop further in vitro, is commonly accepted.

For those who believe that life begins at the moment of fertilisation, preparation of ES cells would be tantamount to destroying a human life. This is the source of the controversy surrounding ES cells. Secondly, the source of these human embryos or ES cells is also relevant. For example, in the case of embryos, were they created solely for research purposes or were they excess embryos left over after IVF treatment? If not used and destined to be discarded in any event, a strong argument could be advanced that it may be morally justifiable to use them in medical research aimed at ultimately benefiting the greater collective.

From a legislative point of view, the preparation of human ES cells and all research involving these cells requires ministerial authorisation in SA.

\section{Induced pluripotent stem cells}

Induced pluripotent stem cells are derived from differentiated human somatic cells which are reprogrammed (dedifferentiated) to a pluripotent state. This is achieved by the introduction and expression of four transcription factors - Oct4, Sox2, KIf4 and c-Myc - into the somatic cells of interest. ${ }^{[29]}$ Reprogramming is a universal process, and has been done in mesodermal, endodermal and ectodermal derivatives including fibroblasts, lymphocytes, liver, stomach, beta cells and neural progenitor cells from a variety of species.

Like ES cells, human iPS cells have the potential to develop into any of the body's cell types and are therefore pluripotent in nature. iPS cells are however easier to produce than ES cells, and are not associated with the same controversial embryonic source, as the procedure does not involve the use of human embryos or oocytes. Obtaining somatic cells (e.g. through a skin biopsy) is also noninvasive, compared to the donation of oocytes used in the SCNT procedure.

One of the primary legal concerns associated with the procurement of iPS cells is the issue of the (genetic) privacy of the cell donor. Unauthorised or inappropriate disclosure of the donor's genetic information holds specific ethical, legal, social and economic risks. Researchers should take special care to protect the privacy interests of donors, for example by measures that will control cross-referencing of information to public databases. The issue of incidental findings also arises, which concerns the inadvertent discovery of a donor's genetic predisposition to a specific condition or disease by the researcher. The question arises as to how to deal with these findings. ${ }^{[30]}$ Informed consent, specifically the withdrawal of consent, poses another challenge. iPS cell lines may also be used indefinitely for future research, which poses an obstacle with regard to voluntary informed consent by research participants. For example, with regard to the various uses of cell lines, donors may morally object to the derivation of human gametes or the creation of human-animal chimeras. The conventional rule that a research participant may withdraw his or her participation at any time during the research is another challenge in this context. If an iPS cell line has been created, may a donor withdraw his or her consent to participate in the research? If so, the consequences for the relevant researcher may be far-reaching. ${ }^{[30]}$

Further concerns that have been mentioned relate to possible downstream uses of the iPS cell derivates, which may include the genetic modification of the cells; large scale genomic sequencing; the sharing of cell lines among researchers; the commercialisation of applications involving the cells; and the possibility of deriving gametes in vitro from IPS cells. ${ }^{[31]}$

With regard to the derivation of gametes, the potential of iPS cells to differentiate into both male and female germ cells in different species, including the development of gametes and offspring in mice, has already been demonstrated. ${ }^{[32,33]}$ This gives rise to intricate legal and ethical issues relating to the sequence and process of reproduction and genetic parentage, not to mention informed consent issues, concerns regarding cloning, as well as the potential to create an embryo by donors who may have no knowledge of such possibility or attempt.

\section{Genome editing of pre-implantation embryos}

Genome editing is the precise and intentional modification of nucleotide sequences in a genome, and has been used successfully in stem cells (including pluripotent stem cells) and adult somatic cells. DNA is inserted, removed or replaced at specific predetermined sites using artificially engineered nucleases or 'molecular scissors'. Engineered nucleases include zinc finger nucleases (ZFN), transcription activator-like effector nucleases (TALEN) and clustered regularly interspaced short palindromic repeats (CRISPR)-Cas9. The ability to treat and/or cure human diseases such as HIV/AIDS, haemophilia, sickle-cell anaemia and several forms of cancer using this technology has generated a great deal of excitement. However, the ability to alter the genome in gametes (sperm, eggs), zygotes (fertilised eggs) and early embryos has raised a great deal of concern. ${ }^{[34,35]}$ This is in part due to the limited knowledge, unpredictable nature and unintended consequences accompanying 'on-target' intended effects, as well as 'off-target' effects, which involve unintended gene editing at sites other than those targeted. These changes will be passed on to subsequent generations and the potential consequences to the individual, their families and society as a whole will need to be carefully considered. In addition, there is the fear that unscrupulous individuals may move towards unsafe or unethical uses of the technology.

Liang et al. ${ }^{[36]}$ have recently published the first set of experiments performed on early human embryos. They found that although the target gene ( $\beta$-globin or $H B B$ ) was effectively cleaved, the efficiency was low and the resultant embryos were mosaic. Off-target effects were also observed. These findings confirm and highlight the need 
to proceed with great caution in human gametes, zygotes and embryos.

In a highly laudable form of 'self-regulation', the global scientific, medical, legal and ethics communities have recommended that the use of these technologies in gametes, zygotes and early embryos in humans be put on hold until there is a greater appreciation of their consequences. The community has called for regulatory measures to be put into place, for the initiation of an open public debate and for open and transparent research which is subjected to peer review.

\section{Clinical translation}

The clinical translation of research conducted on pluripotent stem cells is clearly of immense interest. Safety issues relate in part to the ability of these cells to divide in an autonomous manner, and the ability of these cells to form tumours has been well described.

With regard to ES cells (irrespective of their mode of derivation), clinical trials have to date been limited. One clinical trial has been conducted for spinal cord injury using ES cell-derived oligodendrocyte precursors. This trial was terminated prematurely after treating five patients and has been the subject of much debate. ${ }^{[37]}$ Long-term follow-up of these patients has revealed no clinical improvement or adverse effects related to the treatment. Other clinical trials have utilised ES cell-derived retinal pigment epithelial (RPE) cells for the treatment of a variety of retinal disorders, including age-related macular degeneration. Results to date have revealed possible clinical improvement with no adverse effects related to the treatment. ${ }^{[38]}$

With regard to iPS cells, which are a much more recent discovery than ES cells, a single clinical trial is underway for age-related macular degeneration using iPS cell-derived RPE cells. ${ }^{\left[{ }^{[9]}\right.}$ It is likely, however, that an increasing number of clinical trials will follow, including the use of iPSderived dopamine-releasing neurons in patients with Parkinson's disease.

The question arises as to whether pluripotent cells should be governed by the same regulations that apply to other cell-based products given their unique characteristics and the processes used for their derivation. With regard to their derivation, ES cells will be governed by legislation that governs the use of human embryos. This does not apply to iPS cells. With regard to clinical trials, both cell types and their derivatives would be subjected to the same rules that apply to all clinical trials. In the SA context, these are clearly spelled out in the general regulations made in terms of the Medicines and Related Substances Control Act 101 of 1965. ${ }^{[40]}$

\section{Conclusion}

With the exception of reproductive cloning, which is banned globally, research on human embryos including SCNT, the derivation of ES cells and therapeutic cloning are all permissible according to SA legislation, but according to the NHA and regulations thereto, require ministerial authorisation. Specific matters on which the NHA is silent include egg donation for research purposes, iPS cells and genome editing of preimplantation embryos.

With regard to the use of pluripotent cells or their derivatives for therapeutic purposes, since this is still experimental in nature it would be governed by the rules that apply to clinical trials. These cells would fall under the section of 'biological medicines' in the Guidelines to the Registration of Medicines, ${ }^{[41]}$ to be read in conjunction with the Medicines and Related Substances Act and its regulations. This includes, among others, registration with the Medicines Control
Council and approval from a registered research ethics committee (which implies peer review). Furthermore, patients should not have to pay for these experimental forms of treatment.

Funding. This research and its publication is the result of funding provided by the Medical Research Council of South Africa in terms of the MRC's Flagships Awards Project SAMRC-RFA-UFSP-01-2013/STEM CELLS

\section{References}

1. Bianconi E, Piovesan A, Facchin F, et al. An estimation of the number of cells in the human body. Ann Hum Biol 2013;40(6):463-471. [http://dx.doi.org/10.3109/0301 4460.2013.807878]

2. Nobel Prize.org. The Nobel Prize in Physiology or Medicine. Sweden: Nobel Prize. org, 2012. http://www.nobelprize.org/nobel_prizes/medicine/laureates/2012/ press.html (accessed 14 June 2015).

3. Republic of South Africa. National Health Act 61. Government Gazette 2003.

4. Republic of South Africa. Medicines and Related Substances Control Act 101 Government Gazette 1965.

5. Phuc PV, Ngoc VB, Lam DH, et al. Isolation of three important types of stem cells from the same samples of banked umbilical cord blood. Cell Tissue Bank 2012;13(2):341-351. [http://dx.doi.org/10.1007/s10561-011-9262-4]

6. Wikipedia Foundation. Embryo definition. San Francisco: Wikipedia Foundation. https://en.wikipedia.org/wiki/Embryo (accessed 14 June 2015).

7. Miller-Keane Encyclopedia and Dictionary of Medicine, Nursing, and Allied Health. 7th ed. Philadelphia: WB Saunders, 2003. http://medical-dictionary. thefreedictionary.com/embryo (accessed 14 June 2015).

8. Schoenwolf GC, Bleyl SB, Brauer PR, et al. Larsen's Human Embryology. 4th ed. Philadelphia: Churchill Livingstone/Elsevier, 2009.

9. Wellcome Trust. Wellcome Trust Glossary. London: Wellcome Trust. http://www. wellcome.ac.uk/About-us/Policy/Spotlight-issues/Human-Fertilisation-andEmbryology-Act/Stem-cell-basics/WTD040065.htm (accessed 14 June 2015).

10. www.parliament.uk. House of Lords Stem Cell Research Report; chapter 4: The status of the early embryo. London: www.partliament.uk, 2001. http://www. parliament.the-stationery-office.co.uk/pa/ld200102/ldselect/ldstem/83/8305. htm\#a24 (accessed 25 June 2015).

11. Department of Health and Social Security. Warnock Report of the Committee of Inquiry into Human Fertilisation and Embryology. London: Her Majesty's Stationery Office, 1984. http://www.hfea.gov.uk/docs/Warnock_Report_of_the Committee_of_Inquiry_into_Human_Fertilisation_and_Embryology_1984.pdf (accessed 25 June 2015).

12. Victoria [Australia]. Committee to Consider the Social, Ethical and Legal Issues arising from In Vitro Fertilization, Report on the disposition of embryos produced by in vitro fertilization (Chairman, Louis Waller). Melbourne: Atkinson Government Printer, 1984.

13. Republic of South Africa. Regulations Relating to Tissue Banks in Government Notice R182, Government Gazette 35099 of 2 March 2012. Pretoria: Government Printer, 2012.

14. Hyun I. Moving human SCNT research forward ethically. Cell Stem Cell 2011;9(4):295-297. [http://dx.doi.org/10.1016/j.stem.2011.08.001]

15. Cervera RP, Mitalipov S. Primate and Human Somatic Cell Nuclear Transfer. In: Biology and Pathology of the Oocyte - Role in Fertility, Medicine and Nuclear Reprograming.Trounson A, Gosden R, Eichenlaub-Ritter U, eds. Cambridge: Cambridge University Press, 2013:274-284.

16. Egli $D$, Chen $A E$, Saphier $G$, et al. Impracticality of egg donor recruitment in the absence of compensation. Cell Stem Cell 2011;9(4):293-294. [http://dx.doi. org/10.1016/j.stem.2011.08.002]

17. Haimes $E$, Skene $L$, Ballantyne AJ, et al. ISSCR position statement on the provision and procurement of human eggs for stem cell research. Cell Stem Cell 2013;12(3):285-291. [http://dx.doi.org/10.1016/j.stem.2013.02.002]

18. Zacher A. Oocyte donor compensation for embryonic stem cell research: An analysis of New York's payment for eggs program. Albany Law Journal of Science and Technology 2011;21:323.

19. Republic of South Africa. Regulations relating to Artificial Fertilisation of Persons, Government Notice R175, Government Gazette 35099 of 2 March 2012. Pretoria: Government Printer, 2012

20. Southern African Society of Reproductive Medicine and Gynaecological Endoscopy South African Society of Reproductive Science and Surgery. Guidelines for Gamete Donation. South Africa: SASREG, 2008 http://www. fertilitysa.org.za/Guidelines/ReproductiveMedicine/2008\%20GUIDELINES\%20 FOR\%20GAMETE\%20DONATION.pdf (accessed 14 June 2015).

21. Southern African Society of Reproductive Medicine and Gynaecological Endoscopy South African Society of Reproductive Science and Surgery. Amendment to 2008 
Guidelines for Gamete Donation. South Africa: SASREG, 25 November 2014 http:// www.fertilitysa.org.za/Guidelines/ReproductiveMedicine/Egg\%20donor\%20 compensation\%20-\%20November\%202014.pdf (accessed 14 June 2015).

22. Heindryckx B, De Sutter P, Gerris J, et al. Embryo development after successful somatic cell nuclear transfer to in vitro matured human germinal vesicle oocytes. Human Reprod 2007;22(7):1982-1990.

23. Tachibana M, Sparman M, Woodward J, et al. Derivation of human embryonic stem cells from discarded immature oocytes. International Society for Stem Cell Research (ISSCR), Tenth Annual Meeting. Yokohama, Japan June 13-16, 2012.

24. Noggle S, Fung HL, Gore A, et al. Human oocytes reprogram somatic cells to a pluripotent state. Nature 2011;478(7367):70-75. [http://.dx.doi.org/10.1038/ nature10397]

25. Simerly C, Dominko T, Navara C, et al. Molecular correlates of primate nuclear transfer failures. Science 2003;300(5617):297. [http://dx.doi.org/10.1128/ science.1082091]

26. Byrne J, Pedersen D, Clepper $L$, et al. Producing primate embryonic stem cells by somatic cell nuclear transfer. Nature 2007;450(7168):497-502. [http://dx.doi. org/10.1038/nature06357]

27. United Nations. United Nations Declaration on Human Cloning. GA Res., UNGAOR, 59th Sess., UN Doc. A/280 (2005). http://www.nrlc.org/uploads/international/UNGADeclarationHumanCloning.pdf (accessed 14 June 2015).

28. Reubinoff BE, Pera MF, Fong CY, et al. Embryonic stem cell lines from human blastocysts: Somatic differentiation in vitro. Nat Biotechnol 2000;18(4):399-404. [http://dx.doi.org/10.1038/74447]

29. Yamanaka S. Strategies and new developments in the generation of patientspecific pluripotent stem cells. Cell Stem Cell 2007;1(1):39-49. [http://dx.doi. org/10.1016/j.stem.2007.05.012]

30. Zarzeczny A, Scott C, Hyun I, et al. iPS cells: Mapping the policy issues. Cell 2009;139(6):1032-1037. [http://dx.doi.org/10.1016/j.cell.2009.11.039]
31. Pardo R, Calvo F. Attitudes toward embryo research, worldviews, the moral status of the embryo frame. Science Communication 2008;30(1):8-47. [http://dx.doi. org/10.1177/1075547008319432]

32. Easley CA 4th, Phillips BT, McGuire MM, et al. Direct differentiation of human pluripotent stem cells into haploid spermatogenic cells. Cell Rep 2012;2(3):440 446. [http://dx.doi.org/10.1016/j.celrep.2012.07.015]

33. Ishii T. Human iPS cell-derived germ cells: Current status and clinical potential. J Clin Med 2014;3:1064-1083.

34. Baltimore $D$, Berg $P$, Botchan $M$, et al. A prudent path forward for genomic engineering and germline gene modification. Science 2015;348(6230):36-38. [http://dx.doi.org/10.1126/science.aab1028]

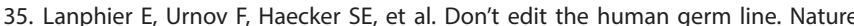
2015;519(7544):410-411. [http://dx.doi.org/10.1038/519410a]

36. Liang P, Xu Y, Zhang X, et al. CRISPR/Cas9-mediated gene editing in human tripronuclear zygotes. Protein Cell 2015;6(5):363-372. [http://dx.doi.org/10.1007/ s13238-015-0153-5]

37. Scott CT Magnus D. Wrongful termination: Lessons from the Geron clinical trial. Stem Cells Transl Med 2014;3(12):1398-1401. [http://dx.doi.org/10.5966/sctm.2014-0147]

38. Schwartz SD, Regillo CD, Lam BL, et al. Human embryonic stem cell-derived retinal pigment epithelium in patients with age-related macular degeneration and Stargardt's macular dystrophy: Follow-up of two open-label phase 1/2 studies. Lancet 2015;385(9967):509-516. [http://dx.doi.org/10.1016/S0140-6736(14)61376-3]

39. Reardon S, Cyranoski D. Japan stem-cell trial stirs envy. Nature 2014;513(7518):287288. [http://dx.doi.org/10.1038/513287a]

40. Republic of South Africa. Government Notice R510, Government Gazette 24727 of 10 April 2003, as amended. Pretoria: Government Printer, 2003.

41. Republic of South Africa. Guidelines to the Registration of Medicines, Medicines Control Council, August 2012. http://www.kznhealth.gov.za/research/mccinfo. pdf (accessed 14 June 2015).

\section{Annexure}

Definitions from the National Health Act and Regulations

\begin{tabular}{llll}
\hline Name & Definition & Source & Comment / proposal \\
\hline DNA & deoxyribonucleic acid, which is a & Regulations relating to the use of human & Proposal - include: \\
& nucleic acid, composed of building & biological material & the sub-cellular component that \\
& blocks called nucleotides & (No. R. 177) & contains human genetic information
\end{tabular}

deoxyribose nucleic acid which is a Regulations relating to the import and export of nucleic acid composed of building blocks called nucleotides

chromosome a thread-like structure made up of DNA found in the nucleus of all cells

gamete

either of the two generative cells essential for human reproduction

oocyte developing human egg cell

the female gamete

sperm the male gamete

zygote

the product of the union of a male and a female gamete

polar body a product that is formed during the development of the female gamete (during meiosis), which contains little cytoplasm and a haploid number of chromosomes human tissue, blood, blood products, cultured cells, stem cells, embryos, fetal tissue, zygotes and gametes

(No. R. 181)

Regulations relating to the use of human biological material

(No. R. 177)

Note: only visible during cell division

ional Health Act

(No. 61 of 2003)

National Health Act

(No. 61 of 2003)

Regulations relating to artificial fertilisation of persons

(No. R. 175)

Regulations relating to artificial fertilisation of persons

(No. R. 175)

National Health Act

(No. 61 of 2003)

Regulations relating to the use of human biological material

(No. R. 177)
Not defined in the Act 
Annexure (continued)

\begin{tabular}{|c|c|c|c|}
\hline \multicolumn{4}{|c|}{ Definitions from the National Health Act and Regulations } \\
\hline Name & Definition & Source & Comment / proposal \\
\hline gonad & human testis or human ovary & $\begin{array}{l}\text { National Health Act } \\
\text { (No. } 61 \text { of 2003) }\end{array}$ & \\
\hline \multirow[t]{2}{*}{ embryo } & $\begin{array}{l}\text { a human offspring in the first } 8 \text { weeks } \\
\text { from conception }\end{array}$ & $\begin{array}{l}\text { National Health Act } \\
\text { (No. } 61 \text { of 2003) }\end{array}$ & $\begin{array}{l}\text { Use of the word 'offspring' is } \\
\text { inappropriate. } \\
\text { Proposal - replace with: the early } \\
\text { stages of human growth and } \\
\text { development, from conception to the } \\
\text { eighth week }\end{array}$ \\
\hline & $\begin{array}{l}\text { a human offspring in the first } 8 \text { weeks } \\
\text { of conception }\end{array}$ & $\begin{array}{l}\text { Regulations relating to the import and export of } \\
\text { human tissue, blood, blood products, cultured } \\
\text { cells, stem cells, embryos, fetal tissue, zygotes } \\
\text { and gametes } \\
\text { (No. R. 181) }\end{array}$ & $\begin{array}{l}\text { Use of the word 'offspring' is } \\
\text { inappropriate. } \\
\text { Use of the phrase 'of conception' } \\
\text { is inappropriate as conception is } \\
\text { generally accepted as the moment } \\
\text { of fertilisation }\end{array}$ \\
\hline $\begin{array}{l}\text { embryonic } \\
\text { tissue }\end{array}$ & tissue from an embryo & $\begin{array}{l}\text { Regulations relating to the import and export of } \\
\text { human tissue, blood, blood products, cultured } \\
\text { cells, stem cells, embryos, fetal tissue, zygotes } \\
\text { and gametes } \\
\text { (No. R. 181) }\end{array}$ & \\
\hline blastocyst & $\begin{array}{l}\text { a pre-implantation embryo consisting of } \\
\text { an outer layer, which forms the placenta } \\
\text { and a } 30 \text { to } 200 \text {-cell inner cell mass, which } \\
\text { develops into the fetus }\end{array}$ & $\begin{array}{l}\text { Regulations relating to artificial fertilisation of } \\
\text { persons } \\
\text { (No. R. 175) }\end{array}$ & \\
\hline \multirow[t]{2}{*}{ fetus } & $\begin{array}{l}\text { a human offspring from } 8 \text { weeks after } \\
\text { conception until birth }\end{array}$ & $\begin{array}{l}\text { Regulations relating to the use of human } \\
\text { biological material } \\
\text { (No. R. 177) }\end{array}$ & $\begin{array}{l}\text { Use of the word 'offspring' is } \\
\text { inappropriate }\end{array}$ \\
\hline & $\begin{array}{l}\text { a human offspring from } 8 \text { weeks after } \\
\text { conception until birth }\end{array}$ & $\begin{array}{l}\text { Regulations relating to the import and export of } \\
\text { human tissue, blood, blood products, cultured } \\
\text { cells, stem cells, embryos, fetal tissue, zygotes } \\
\text { and gametes } \\
\text { (No. R. 181) }\end{array}$ & $\begin{array}{l}\text { Use of the word 'offspring' is } \\
\text { inappropriate }\end{array}$ \\
\hline fetal tissue & tissue from a fetus & $\begin{array}{l}\text { Regulations relating to the import and export of } \\
\text { human tissue, blood, blood products, cultured } \\
\text { cells, stem cells, embryos, fetal tissue, zygotes } \\
\text { and gametes } \\
\text { (No. R. 181) }\end{array}$ & \\
\hline $\begin{array}{l}\text { primordial } \\
\text { germ cells }\end{array}$ & $\begin{array}{l}\text { stem cells found in the gonad of a } \\
\text { fetus capable of becoming ova or } \\
\text { sperm }\end{array}$ & $\begin{array}{l}\text { Regulations relating to the use of human } \\
\text { biological material } \\
\text { (No. R. 177) }\end{array}$ & \\
\hline $\begin{array}{l}\text { embryonic } \\
\text { stem cell }\end{array}$ & $\begin{array}{l}\text { any cell from the } 30-200 \text { inner cell } \\
\text { mass of the blastocyst }\end{array}$ & $\begin{array}{l}\text { Regulations relating to the use of human } \\
\text { biological material } \\
\text { (No. R. 177) }\end{array}$ & \\
\hline $\begin{array}{l}\text { reproductive } \\
\text { cloning of a } \\
\text { human being }\end{array}$ & $\begin{array}{l}\text { the manipulation of genetic material } \\
\text { in order to achieve the reproduction of } \\
\text { a human being and includes nuclear } \\
\text { transfer or embryo splitting for such } \\
\text { purpose }\end{array}$ & $\begin{array}{l}\text { National Health Act } \\
\text { (No. } 61 \text { of } 2003 \text { ) } \\
\text { Section } 57(6)(a)\end{array}$ & $\begin{array}{l}\text { Proposal - replace with: } \\
\text { the manipulation of cells, gametes, } \\
\text { zygotes or embryos or genetic material } \\
\text { derived therefrom in order to achieve } \\
\text { the reproduction of a human being } \\
\text { and includes but is not limited to } \\
\text { nuclear transfer and embryo splitting }\end{array}$ \\
\hline $\begin{array}{l}\text { therapeutic } \\
\text { cloning }\end{array}$ & $\begin{array}{l}\text { the manipulation of genetic material } \\
\text { from either adult, zygotic or embryonic } \\
\text { cells in order to alter, for therapeutic } \\
\text { purposes, the function of cells or tissues }\end{array}$ & $\begin{array}{l}\text { National Health Act } \\
\text { (No. } 61 \text { of } 2003 \text { ) } \\
\text { Section } 57(6)(b)\end{array}$ & $\begin{array}{l}\text { Definition should include } \\
\text { somatic cell nuclear transfer }\end{array}$ \\
\hline
\end{tabular}

